Pragmatism, Rights, and Democracy 


\section{American Philosophy Series}

1. Peirce and Contemporary Thought, edited by Kenneth Laine Ketner

2. Classic American Philosophers: Peirce, James, Royce, Santayana, Dewey, Whitehead, ed. Max Fisch, second edition Introduction by Nathan Houser

3. John E. Smith, Experience and God, second edition

4. Vincent G. Potter, Peirce's Philosophical Perspectives, edited by Vincent M. Colapietro

5. Philosophy in Experience: American Philosophy in Transition, ed. Richard E. Hart and Douglas R. Anderson

6. Vincent G. Potter, Charles S. Peirce: On Norms and Ideals, second edition

Introduction by Stanley M. Harrison

7. Reason, Experience, and God: John E. Smith in Dialogue, edited by Vincent M. Colapietro

8. Robert J. O'Connell, s.J., William James on The Courage to Believe, second edition

9. Elizabeth Kraus, The Metaphysics of Experience: A Companion to Whitehead's Process and Reality, second edition Introduction by Robert C. Neville

10. Pragmatism, Reason, and Norms: A Realistic Assessment, edited by Kenneth R. Westphal 


\title{
Pragmatism, Rights, and Democracy
}

\author{
Beth J. Singer
}

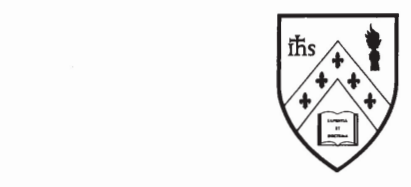

FORDHAM UNIVERSITY PRESS

New York

1999 
The text of this book is licensed under a Creative Commons Attribution-NonCommercial-NoDerivatives 4.0 International License: https://creativecommons.org/licenses/by-nc-nd/4.0/.

Open Access edition funded by the National Endowment for the Humanities/ Andrew W. Mellon Foundation Humanities Open Book Program.

\section{क्री Humanities}

(C) Copyright 1999 by FordhAM UNIVERSITY PrESS

First Open Access edition, 2019

To use this book, or parts of this book, in any way not covered by the license, please contact Fordham University Press, Rights \& Permissions, Joseph A. Martino Hall, 45 Columbus Avenue, New York, NY 10023-6917, or copyright@fordham.edu.

LC 98-23028

ISBN 0-8232-1867-8 (hardcover)

ISBN 0-8232-1868-6 (paperback)

ISSN 1073-2764

American Philosophy Series, No. 11

Vincent M. Colapietro, Editor

Vincent G. Potter (1929-1994), Founding Editor

Visit us online at www.fordhampress.com.

Library of Congress Cataloging-in-Publication Data

Singer, Beth J., 1927-

Pragmatism, rights, and democracy / Beth J. Singer.

p. cm.-(American philosophy series : no. 11)

Includes bibliographical references and index.

ISBN 0-8232-1867-8 (hardcover). — ISBN 0-8232-1868-6 (pbk.)

1. Human rights. 2. Community. 3. Individualism.

4. Pragmatism. I. Title. II. Series

JC571.S6285 1999

323'.01-dc21

98-23028

CIP

Printed in the United States of America 
To my colleagues and students in the

Brooklyn College Philosophy Department 
